\title{
Dust and Joys: A Tale from the Alternative Archives
}

Once, in a city, there was a Chef, the darling of every gourmand, the envy of all cooks and, much to their dismay, the indisputable idol of their young apprentices. His celebrated entrée Denouement de Saumon au Coup de Grace had, upon its inauguration, provoked such an insurrection on the City Mayor's taste buds that, while pressing a silver-lined napkin to his tear-filled eyes, this notoriously unflappable statesman went so far as to clamor for the Chef's hand in marriage. The much desired Torte des Pommes des Hesperides (avec Crème de la Crème) was rumored to contain not only twenty-three plant extracts and five distinct qualities of flour, but also an innocuous quantity of rare snake venom. The rainbow-colored Galantine au Contraire, served with crisp thorns of Kalahari cactus en croute, was said to convert even the staunchest atheists to pagan practices of nature worship.

Serious housewives knew to paste his recipes onto the refrigerator, and took great pains to replicate them for dinner-parties. Photographs of his tastefully arranged dishes hung in the finest art galleries. On the dark, wooden walls of his restaurant, shelved gold and silver trophies shimmered under discreet, gas-lit lamps with an air of promise that could be felt from the moment the patrons set foot inside.

But these many achievements were not enough for the Chef. For some time, he had secretly nourished a formidable project: to experience the ultimate degustative thrill, to taste the combination of foodstuffs supreme, a marriage of flavors so delectable that the sheer pleasure of it would kill upon consumption. He had conceived of this notion in his early adolescence, during episodic trances induced by a blend of cannabis, nutmeg and poppy-seed that his mother kept hidden in the office cabinet. On occasion, she filled her pipe with the mixture and spent long hours on the roof, smoking(a habit his father never suspected, although even after his wife's death from lung-cancer, he often stepped into the office and stood there, sniffing quietly at the lingering scent, nostrils quivering with a puzzled thrill. 
Each day the Chef pulled on his white-starched cap with the solemnity of a soldier preparing for battle and marched downstairs into his restaurant kitchen to immerse himself in the steam from yellow fish broths and simmering chiffonades. Under strung-up sprays of dried marjoram and pimpernel, he lifted the lids off braziers filled with bubbling stews, sniffed the cooling quince-pies on the stove-top, frowned and haw-hummed at the rising brioche paste. He lined up his staff and delivered lectures such as The Versatility of the Corozo Nut: from al dente to vol-au-vent and Smothering the Duck: a Matter of Empathy. The Grand Plan, however, lingered stubbornly in the attic of his mind, and he could not set his eyes on a dish without considering how its form or taste might enhance the repast of his dreams.

In an interview conducted by a petite, pencil-tapping journalist, the Chef declared that the loveliness of textures, flavors and temperatures on the tongue was the sole reason he walked the earth. And wasn't it true, inquired the young lady (leaning towards him because she was discovering the irresistible scent of vanilla and salted butter that seemed to emanate from his skin) that he undertook regular expeditions to scour the continents for new ingredients? Hadn't he, for instance, brought home previously unknown aromatic plants from the Australian rainforest, and a new type of glutinous grain from the Mongolian grasslands, which he had put to successful use in creating a pound-cake entirely eggless? (Her pen had surreptitiously stopped tapping, and, nostrils flared, she licked her large, robust teeth, a prominent feature of her face which, incidentally, she despised.) $\mathrm{Hm}$ - the Chef magically produced a crystallized celery-heart, and placed it delicately in her half-open mouth-yes, he said. It was true. His very competent sous-chef had been invaluable to him all these years, running things all by himself for weeks on end, when necessary.

The journalist closed her eyes as lemon and caramel dissolved on her tongue, leaving the curious briskness of cellulose. The Chef smiled; did she know she had very passionate teeth? Later that evening, as she returned home with wine-stains on her half-buttoned shirt, hair wildly disheveled and skin still tinged with his scent, she wrote a turbulent feature entitled Love, Death and the Kitchen Gods. She went on to become one of the most respected 
food-critics of the country, known for her unusual method of delicately uncorking bottles of wine with her front teeth.

What the Chef did not mention to her-or to anyone else-was that all this traveling also advanced his private search for the vials that would make up his Last Supper of the senses. He had consulted all manner of cook books, spice dictionaries, alchemist's formulas and manuals of love-making. Still not satisfied, he proceeded to climb incredible altitudes, seeking advice from mystics who preached obscure philosophies to an audience of circumspect eagles. He visited ill-humored magicians who bred pigeons in the middle of extremely deep lakes, and even made an appointment with a certain Icelandic Countess in scanty clothing, who was rumored to know the secrets of eternal bliss-all the while collecting exciting, crisp ingredients and long-lost cooking lore.

It was during one of these pilgrimages that he met his wife. He happened upon a secret, blossoming wine-valley in the middle of a desert, from which originated a large-boned, rather aggressive wine-though, one must admit, very truthful in character, if allowed some time. Once a year, a procession of patient camels lugged flagon after flagon of wine to the closest city for sly distribution into the world market, unadvertised except by word of mouth. The Chef made sure to establish a direct trade contract immediately and in fact, this intriguingly tenacious red remained a favorite in his restaurant for many years.

Outside the cool-storage cellars, fleet-footed grape-treaders trampled and sweated under a scorching sun. They lived on grapes and mangoes and roasted snakeflesh, and a flat, reddish bread made of native grains. While taking notes on the bread recipe during a break, the Chef noticed a young woman taking large draughts of icy spring water, her face turned up and her eyes closed as though imbibing the sweetest of nectars. Her skin was black as the shiniest aubergine. Her eyes floated towards him like glimmering goblets of champagne, wide-open in wonder at the whiteness of his skin.

The soft-spoken vintner-mysteriously green-eyed and wellversed in foreign languages - whispered to him that she was an orphan, raised by aunts and uncles. She was of a peculiar breed, he explained. Her eyes and feet roamed constantly towards the edge of the desert, as if pulled by the enigma of what lay beyond. This 
had become a constant source of distress to her family, for who would want a wife that didn't stay in place? Who would want a mother who was always sniffing the wind for hints of foreign things?

The seduction took place among the hush of wind-lulled grape 162 leaves, as she plucked clusters of heavy, shimmering grapes that cascaded through her small fingers, and held them up to his mouth. He produced a softened cognac-truffle he had kept in his pouch for emergencies, unwrapped it from the pink foil and offered it to her. She frowned and gave it a suspicious lick, then bit into it, and smiled with brown-smeared lips. Their bodies came together in silent agreement, and the grapevine closed in on them quietly, without any comment. When he asked her to return with him, she put her elephant-bone spoon and a handful of dried figs in a leather pouch, swept a blood-red cloth over her head and bid her aunts and cousins good-bye with dry kisses on their foreheads. She was going to a barbarian country, she explained, where they made food that looked like excrement, but tasted like heaven. Then she marched over the desert with him, her back straight the whole way.

The first room he showed her was the kitchen. The restaurant staff looked on breathlessly while she lowered her headcloth and sniffed in the air. She touched the shining edge of knives and cleavers, ran her hand along the smooth metal of the sink, dipped her spoon into the rose-tea mousse and the deep-red goulash, grimacing with delight as they made contact with her tongue. She leaned her cheek against the rough crochet of the pan-holders and poked a finger into the cloud of the sous-chef's cap. She found the jars of palm-flower juice and almond milk in the refrigerator; these she held up to her face and inhaled for long moments, before she looked up at the Chef, radiant.

He wed her in a discreet living-room ceremony, to the sound of larks and thrushes from the herb garden, and in plain attire (though she insisted on wrapping his lace curtain around her shoulders, which suited her marvelously). They indulged in a few small luxuries: caviar-canapés, truffle-stuffed oysters in a bed of sinuous horseradish ribbons, champagne with bubbles like jewels and fiori de latte ice-cream with violets. The wedding was attended only by his aging father-who sat in a wheel-chair sniffing the air 
with a suspicious frown, as if the faint smell of spices held some familiar secret - and by the kitchen staff, requiring much persuasion and several glasses of champagne before they could bring themselves to sit on the sofa, nibbling shyly on the dainties they themselves had prepared.

His new wife spent that night pointing to different parts of her body, naming them in her language and learning them in his. Clavicle, he said, running his finger over her bones. Perineum. She repeated after him, shaping her mouth in a caricature of his: navel? Pa-late? His stare was so hungry that there was no fitting her within the boundaries of his orbital cavity, and finally she laughed and placed a hand over his lids. In the short instant of that fingercooled darkness, he realized that he had finished searching the planet for the deathly bliss of his dreams. The answer, he now saw, could be found nowhere but within. He had to create it himself, let it flow from his innermost passions and philosophies.

Together they raised two large and demanding twin daughters, both of whom inherited their father's exacting attention to detail, though not his grand visions of towering pastry castles or epic, world-stopping marinades. The minute they were safely out of the womb, brown and smooth like marron glacé, he served them a fingertip of glistening, black caviar, and they had never ceased clamoring for more. Only because he taught them early that enjoyment was not possible without temperance and moderation, did they not spend every minute of their lives sucking and smacking and chewing. And so they became two incontrovertible gourmands, who oversaw the restaurant kitchen with as much conviction as their father, and at least twice the despotism.

At first, his wife discovered delightful strangeness every day: the bathtub, the raspberries, the many colors of hair. But after a few years, her yearning for distant things was renewed. Again her feet were pulled to the edges of the city, where afternoons she could be seen sniffing the air, catching delicate traces of the unknown. In the evenings, sipping lotus tea by the cooling bread oven, she asked him: couldn't they go elsewhere? Couldn't they take a bus or a train and go, all the way to the end of things? And the Chef replied that he had wandered almost there, almost to the end of things, only to conclude that, rather than without, it lodged within. He still needed some time to prove as much, however; if she 
could only wait a little, he would then gladly accompany her anywhere she desired.

So while his wife and daughters spent the mornings tending the thriving herb garden, scrubbing and sweeping their living quarters on the floor above the restaurant, or putting their shrewd, blackbraided heads together over the riddles of accounting, the Chef plunged wholeheartedly into secret experimentations in the kitchen, elaborating several versions of his ultimate concoction as he attempted to reach the perfect balance between pleasure and obliteration.

The mixture he started with contained two ancient aphrodisiacs-one, a mixture of spices and nuts from India, another a certain dried herb reputedly from Gramarye. To this he added two types of poison-one, obtained at a high price in the shadowy underworld of his city: a slow-working substance which induced a lazy dream-state, gradually overpowering all senses until the victim floated away blissfully in the folds of Death's manteau. The other, a concentrate from a Polynesian root, which caused strong infusions of euphoria, bursts of feeling which became so unbearable that they led to explosion of the internal organs. He experimented with varying proportions of these ingredients, adding to them mild hallucinogens, oils, spices and thickening agents.

Periodically, he soaked a sugar cube in this brew, placed it on the windowsill and waited for the ants to come. Thus, he could assess their level of excitement before they scurried into confused death, frequently throwing themselves over the wooden ledge, if not drunkenly waving their antennae and falling on their backs while trying to rise on their hindlegs. Later on, as he came to need subjects that would show more readable signs of delight and suffering, he turned to the rabbits that were bred by the chicken coop, certain that they preferred this destiny to the usual skinning and drawing.

The best ratio between the duration and the fatality of the pleasure, he concluded, was to be found in two parts aphrodisiacs, one part hallucinogenic, one part protein and complex carbohydrates, and one part a combination of various poisonous substances. By the time his daughters were both married with three children each, he had arrived at a brown, syrupy substance that could be had hot or cold, if thickened with some fine-sifted flour 
into a pudding-like texture. It was just then that his dauntless and beloved wife betrayed a sudden decline in health.

Lately she seemed to have settled into contented grandmotherhood, having ceased to speak of the day when they would set out to reach the limits of the world. Now, though, she began to have dizzy spells in the midst of the household tasks, and on several occasions was found lying on the bare floor, breathing very slowly, unable to move. She waved her alarmed family members away, explaining that she needed to 'concentrate'. Even while her ample appetite remained unabated, she began to cough up strange, bronze-tinged spittle into her cotton handkerchief, and her hairdespite its healthy shine-started coming off in large tufts which could be observed hovering over the ventilation shafts. Although she still hummed grape-treading songs over the basil and the fenugreek patches, her voice grew hoarse and tired and she closed her eyes for long naps after every meal. But when the Chef kept away from her bed so she could rest, she protested vigorously and, in fact, appeared to enjoy his caresses even more than in the past. And because of this strange phenomenon-that she seemed to glow and thrive, even as she became weaker and weaker-it took some time before he decided to consult a doctor.

The physicians pronounced it an unknown kind of blood disease. There was nothing they could do, they said, nothing at all. The Chef did not want to believe this; he felt certain that there must be a cure, and secretly cursed himself for not having dedicated all his years to medical recipes rather than to a miserable death potion. The daughters wiped away their tears and consoled him; at least she seemed happy and comfortable, peculiarly resigned to her approaching demise. His wife only smiledindeed, she was in a state of bliss, and professed to wish nothing more than to lie in bed, delighting in the wafts of kitchen air from downstairs and knowing that her loved ones worked there. The daughters took charge, notifying their mother's family by mail, and arranging for her care at home.

Soon, she was too ill to get up, and spent her days sleeping fitfully, her eyes moving quickly under the lids. When she awoke, she reported dreams in which transparent, ethereal beings floated down a frothing river on a block of ice, sipping red wine that settled into their stomachs and seeped out between their legs like a 
woman's blood; dreams in which whole deserts made of sugarcrystals crunched under your bare feet, and by listening for subtle vibrations in the ground, you could dig up delightfully decorated confectionery, warm cakes and breads that crackled and sputtered like new-born continents.

166 A flurry of visiting relatives sat around in the living-room drinking very strong tea boiled with milk and erected an altar with red and gold cloths, where they burned incense for gods she had never mentioned to her husband. From her deathbed, she motioned at him to feed them, by all means, and while new arrivals placed bowls of grapes and mangoes before the shrine, his daughters passed around platters of deviled froglegs and lobster-chestnut canapés, which caused much puzzlement, murmuring, and careful sniffing before they were enthusiastically consumed.

One day when the Chef brought her regular dinner of favorite tidbits from the restaurant, she grasped his hand and made him sit on the bedside. He would never forgive her, she began — and then proceeded to confess, in a jumble of words which took him some time to decipher, that she had known all along about his secret ministrations in the kitchen. Mystified by his secrecy and unaware of his exact purpose, she had spied on him and sneaked in at night to smell his potions; first tasting them about three years agobarely a teaspoonful. The stuff had given her such a thrill that she had not resisted trying it again, and again, until she could not bear to be awake without it. By then, she could not have stopped even had she wanted to, even though she was beginning to understand that it was killing her. Yes, even when the full implication of what he had been trying to do all these years finally dawned on her, she had not been able to control herself.

She kissed the palm of his hand, assuring him that she did not care; every sip had been worth tenfold the years she could have lived if she had not tasted his masterpiece. If she hadn't already worshipped him, she would have loved him solely for making possible such an experience. Now she could see that the inside was truly much larger than the outside.

Until two days ago, she had, in spite of her weakness, slipped into the kitchen every night to feed her habit. But now she was too weak to get it herself. Would he? 
The Chef sat by her in silence for a long time, while something inside him crumbled slowly, like a shuddering mountain of sugar. He went down to the kitchen and stood in front of the neat rows of cleavers, skewers and paste pinchers on the wall. He could hear the chattering of the guests upstairs and the drip-drip of curdling cheese in the pantry. He rolled up his sleeves. If she was going to die, he thought, he would give her the last, perfect incarnation of his potion.

Around midnight, an unparalleled fragrance began to rise from the bursting bubbles in his large pot. The Chef dipped his face into the vapor, and his nostrils quivered like a leaf under a quick drop of rain. Several spiders that had been concealed in the dust, as well as flies, a grasshopper and two moths, drifted irrevocably towards the scent. He had to skim their bodies off the surface and cover the pot with a lid, upon which the bugs still gathered, notwithstanding the heat that singed and curled their legs. At this point he scooped part of it into a bowl and used it as the base to prepare a delightfully airy souffle - the dainty his wife had most marveled over in the first days of her arrival.

Early the next morning he explained the situation to his daughters, who shook their heads. To die for pleasure! they said reproachfully. Nevertheless they touched their mother's cheeks with curiosity, to examine the enticing texture of excess, and they agreed that, at this stage, there could be no better way.

He brought in the Grand Meal, perfumed and frothy, steaming on a silver plate, followed by two eager birds who flapped their wings nervously and threatened to land right in the middle of the soufflé. With no sympathy for the burning desire that drove the fledglings to risk their necks, the twins chased them away and locked the door. A few houseguests peeked out of their rooms, wondering where this heavenly smell came from, and the others had dazzling dreams they would always remember.

The daughters licked their lips and watched their father direct shivering spoonfuls carefully into his wife's greedy mouth. She proceeded immediately to die, before their eyes, in paroxysms of pleasure, swallowing the remainder even as she expired. She grasped their hands, and, in a sighing whisper, uttered her last words: "Perhaps one more grain of salt-" 
The cremation was performed according to the rituals of her people, who built a pyre of scented wood in the garden, at the center of which they gently placed their departed child, nodding in approval when the Chef deposited a sugar-coated rose in her hands. They surrounded the body with blue gem-stones in the rough. (The women had apparently smuggled these into the country by wrapping them in their elaborate hairdos-joys, they called them, which the Chef took to be a mispronunciation of 'jewels'.) Mourners in ochre and turquoise performed cajoling, dance-like dialogues with the spirits to the tune of musical lamentations and the subdued chatter of pearly-toothed children. When the fire died down, there were only ashes and an oval outline of gems-aquamarine eyes in a bed of dust - collected, with much ceremony, by a bony, black-lipped old woman.

When the last of the relatives were gone, each carrying a thimbleful of ashes to be released to the desert winds, the old woman pressed one of the gem-stones and a small leather-pouch of ashes into the Chef's hands, explaining that the husband was entitled to keep his portion of joys and love-dust until he died, when they should be mingled with his own ashes. When the door closed after her, his daughters cleaned up, kissed him and went back to their families, admonishing him to get some rest.

The Chef, however, had other plans.

He bathed and donned a crisp, fresh uniform, combing his hair and eyebrows before going to the kitchen. His hands trembled as he set the heat on low under the large pot. Then, on a sudden whim, he retrieved the small pouch from the pocket of his trousers, and, without thinking twice, poured his wife's ashes into the pot. They drifted cloudily over the steaming surface for a moment, before settling within it. The gem-stone slipped in by mistake, producing a small 'plonk' as it hit the bottom.

When he had once more prepared the same soufflé that had carried his wife away, he took a deep breath, and placed the first spoonful on his tongue. He closed his eyes. His mouth was filled with sheaths of cumulocirrus clouds, with the smoothness of lacquered wood and the liquid warmth of a mother's womb-his palate was attacked by minute, separate tastes which, despite the undeniable integrity and fullness of each bite, pricked his tongue and the sides of his mouth like exquisite instruments of the most 
pleasing torture. His nostrils widened and he inhaled all the scents of the earth simultaneously; the ripening of strawberries in the sun, his mother's slow-boiling oxtail stew, the perfume on a woman's wrist held to his lips; each one invaded him in tortuous slow motion, filling his head, his lungs and his whole being until he was sure he could contain no more, but found that he could.

On the second taste, his field of vision expanded to encompass every last blade of grass in the universe, as if he floated just above the ocean foam, like a kiss whereby your lover melted and flowed into your mouth by degrees until contained within you. He could sense the dust of butterfly-wings and spider legs under his feet; he could smell the ancient scent of long-vanished lakes and decayed bones in the earth.

By the third spoonful, he was immersed in a watery glow that lifted and caressed him with a thousand sea-anemone fingers, their warmth penetrating his pores, and with each new portion, his insides swelled voluptuously, excruciatingly aware of the delicate morsel that journeyed slowly into his stomach. He could feel the blood that flowed through each vein and artery in his body, caressing its walls like the lightest of kisses. When his inner organs rubbed accidentally together, they were as deliciously sensitive to touch as would be an exposed nerve that could feel no pain. Finally he lifted the plate to his mouth and wolfed down the remains like a beast.

When the explosion came-although it was so slow that it seemed not like an explosion but like the endless outward pulsation of the universe - it did not shrink back into itself like a sneeze or a sexual climax, but went on and on, expanding until no substance was left, only a multitude of particles growing further and further apart. They would recede beyond the stars, and there could be nothing afterwards but silence. So this is the nature of True Pleasure, was his last, dim thought. It can only be had once.

His daughters found him the next morning, slumped on the floor and still clutching the plate, his face frozen in rapture. They looked at him and then at each other, not disdaining to shed a few tears. The odor of their father's potion was compelling, but they knew very well that whoever tasted it would experience the most lethal delectation. And so, before calling the coroner, they covered their mouths and noses with handkerchiefs and undertook to get 
rid of the whole thing by dumping it carefully in the wood-fired stove and letting it burn for a whole day. The house became infused with a strong, intoxicating aroma, and later they found myriads of dead insects, squirrels, birds and cats on the roof, all of whom were gathered around the chimney and had dropped as if in 170 mass-suicide. The scent had penetrated the very being of the house, which creaked and shuddered in delight. Shaky but invigorated with the odor, the daughters swept the roof and sent the remaining ashes floating on the wind.

And so it was that the Chef, much mourned by his city, left an enduring legacy in form of his Grand Meal, which now flurried about in the diluted form of dissipated smoke and scattered ashes, sneaking and seeping into the most unlikely places. A rat-filled sewage pipe was suddenly thrown into hectic frenzies that no one but the rats and the cockroaches would ever have knowledge of. Ecstatic geese could be seen whirling elegantly amid atmospheric pressures as if begging passing tornadoes and typhoons to carry their limbs away, each separately. Certain flowers bloomed in record time into unrivaled colors and smells, before they sank, exhausted but fulfilled, and weighed to the ground by hoards of eager bees. The city's sons and daughters, if they paid attention, could encounter this heavenly whiff of death when least expected: in a lungful of smoke or a mouthful of sweetness, in a morsel of sharp cheese or a warming sun-ray. And when they did, they trembled with pleasure. As a famous food critic with large, coffeestained teeth had once said: to live is to die, little by little, and like tea and sugar or bread and butter, pleasure and death must be taken together.

In the secret wine-valley, the old, black-lipped woman received perfumed letters from the twin-daughters, and before she brought them to the green-eyed vintner for translation, she sniffed them and thought, they smell of dust and joys. 